\title{
REPORT OF THE WORKING GROUP ON THE UNIVERSAL PERIODIC REVIEW. MEXICO*
}

\section{INTRODUCTION}

1. The Working Group on the Universal Periodic Review (UPR), established in accordance with Human Rights Council resolution 5/1 of 18 June 2007, held its fourth session from 2 to 13 February 2009. The review of Mexico was held at the 13th meeting on 10 February 2009. The delegation of Mexico was headed by H. E. Sr. Fernando Gómez-Mont, Minister of Interior. At its meeting held on 13 February 2009, the Working Group adopted the present report on Mexico.

2. On 8 September 2008, the Human Rights Council selected the following group of rapporteurs (troika) to facilitate the review of Mexico: Nicaragua, Pakistan and South Africa.

3. In accordance with paragraph 15 of the annex to resolution $5 / 1$, the following documents were issued for the review of Mexico:

(a) A national report submitted / written presentation made in accordance with paragraph 15 (a) (A/HRC/WG.6/4/MEX/1);

(b) A compilation prepared by the Office of the High Commissioner for Human Rights (OHCHR), in accordance with paragraph 15 (b) (A/HRC/WG.6/4/MEX/2);

(c) A summary prepared by $\mathrm{OHCHR}$, in accordance with paragraph 15 (c) (A/HRC/WG.6/4/MEX/3).

4. A list of questions prepared in advance by the Czech Republic, Denmark, Germany, Liechtenstein, the Netherlands, Sweden and the United Kingdom of Great Britain and Northern Ireland was transmitted to Mexico through the troika. These questions are available on the extranet of the UPR.

* United Nations, A, General Assembly, General Distribution, A/HRC/11/27, 3 March 2009, Original in English. Human Rights Council, Eleventh Session, Agenda item 6. Previously issued under symbol number A/HRC/WG.6/4/L.13; minor revisions have been added under the authority of the secretariat of the Human Rights Council, on the basis of editorial changes made by States through the ad referendum procedure The annex to the present report is circulated as received. 


\section{SUMMARY OF THE PROCEEDINGS OF THE REVIEW PROCESS}

\section{A. Presentation by the State under review}

5. At the third meeting, on 10 February 2009, the Minister of Interior of Mexico presented the national report. He explained that Mexico participates in the UPR mechanism out of conviction that promoting and protecting human rights is a non-renounceable obligation and a universal ethical imperative and that cooperation with the international human rights mechanisms is an invaluable tool to foster internal structural changes.

6. He indicated that legislators and officials of autonomous human rights bodies were present in the room, as well as Mexican non-governmental organizations (NGOs). He recognized remaining challenges, mainly: strengthening the rule of law, so that security and justice institutions are fully capable of protecting all citizens and human rights are fulfilled in a context of authentic democratic governance; and overcoming the inequalities that characterize the Mexican society, particularly through poverty reduction and eradication of extreme poverty.

7. Mexico's democratic consolidation has profoundly transformed political, legal and social institutions, resulting in effective separation of powers; a broad network of public human rights bodies; a more active and participative civil society; the strengthening and harmonization of the legal and institutional framework for promoting and protecting human rights; and full cooperation with and openness to international mechanisms of human rights scrutiny.

8. Under the Constitution, international treaties on human rights are supreme law and above federal and local laws, and can therefore be invoked before tribunals. Mexico faces challenges in legislative harmonization at the state level.

9. The Congress is now considering several bills to fully embody the concept of human rights in the Constitution.

10. Mexico has developed and consolidated a large number of institutions and public policies for the protection of human rights, for example, the National Human Rights Commission and the network of local human rights institutions. Mexico has a National Human Rights Programme (NHRP) which is the core guideline for the consolidation of a comprehensive State policy on human rights. Additionally, the Commis- 
sion for Governmental Policies on Human Rights, which is a permanent mechanism for dialogue between the federal government and NGOs, has fostered relevant legislative reforms.

11. Permanent cooperation with international human rights mechanisms has become a key factor in strengthening national legislation, institutions and public policies.

12. The report presented by Mexico is based on the premise that corruption, public insecurity and impunity are a threat to human rights. Organized crime has killed citizens, journalists, prosecutors, police officers and members of the armed forces. Criminal groups use kidnappings, blackmailing and violence, and also employ corruption against institutions, eroding them and violating the rights of Mexicans. The largest threat comes from organized crime. Therefore, the struggle to ensure law and order in Mexico is essentially a fight to safeguard fundamental liberties and rights of all citizens. In some regions of the country, criminals have launched a total offensive against society, surpassing the logistic and combat capabilities of certain civil authorities. The current Administration deems as necessary the participation of the armed forces in support of civil authorities facing organized crime. The service so provided by the armed forces is invaluable, recognized by Mexican society and in accordance with the constitutional framework. The deployment of the armed forces is subsidiary and exclusively at the request of civil authorities, and strictly temporary. The delegation was aware of concerns regarding alleged human rights violations committed by members of the armed forces while carrying out public security tasks, as well as concerns about the functioning of military justice in Mexico, but reiterated the commitment of the security forces involved in the fight against organized crime to fully respect all human rights of all.

13. The judiciary and the permanent oversight by the autonomous human rights institutions, the media and public opinion play a key role in ensuring that alleged human rights violations are investigated and prosecuted. The NHRP includes the commitment of the military forces to promote reforms in the field of prosecution and administration of justice before military tribunals in accordance with Mexico's international obligations. The Ministry of Defence has specialized units to receive and process complaints and recommendations from autonomous human rights bodies through administrative and criminal procedures, including redress procedures. Complete harmonization with international human 
rights standards requires further regulating and professionalizing the security forces, especially with respect to the legitimate and proportional use of force in the fight against organized crime. As a result of the events in Atenco, the Supreme Court is examining the adoption of international standards on the use of force by security corps.

14. The delegation highlighted the Government's launching of an in-depth-transformation of the criminal justice system with two main goals: ending impunity and strengthening the State capacities for crime prosecution, with full respect for human rights. In 2008 the Reform to Public Security and the Criminal Justice System set an accusatory system, and strengthened: the guarantees of due process; the presumption of innocence; full respect for victims' rights; and effective protection against abuses by authorities. The reform consistent with the Palermo Convention reinforces the State capacities to investigate, prosecute and punish crimes, ensuring full respect of human rights.

15. In recent years there have been important improvements regarding access to public information and de-penalization of press crimes. The delegation shared the concerns about the security of journalists, stressing that violence threatening journalists and information providers comes from criminal organizations. The Federal Executive has just introduced a bill before Congress to make attacks against journalists a federal crime.

16. Combating torture is a government priority. The Constitution prohibits torture, and corresponding national and federal legislation has been enacted. Nevertheless, Mexico needs to harmonize laws against torture throughout the country, implement the Istanbul Protocol in all states and work, including with civil society, to create a national registry of allegations of torture.

17. The Constitution prohibits all forms of discrimination, and Mexico has a Federal Act to Prevent and Eliminate Discrimination and a National Council for the Prevention of Discrimination on this issue. Discrimination against women, especially if it involves violence, is a main concern and a high priority, and Mexico is aware of the significant challenges in this domain. Most states have harmonized their laws with the General Act on Women's Access to a Life Free From Violence, and have a state system against violence. Mexico has also put in place public policies in support of gender equality. In addition, the new General Act on Equality between Women and Men promotes women's empowerment at the federal level in both the public and the private spheres. The federal 
Special Prosecutor's Office on Violent Crime against Women and Human Trafficking has initiated several investigations. Training and awarenessraising programmes for the judiciary have been developed. Particular indignation was expressed by many regarding the killing of women, especially the cases in Ciudad Juárez, Chihuahua. The State institutions will work with civil society to fully address these crimes and to prevent them. Both at the national level and in the case of Ciudad Juárez, important efforts are under way to enhance legislation and strengthen institutions and budgets.

18. With regard to specific groups, the Federal Government has taken important steps in shifting from welfare to a rights-based approach. Access to health, freedom from violence and equal opportunities have to be provided to all children in Mexico, through the implementation of inter-institutional and comprehensive programmes for children focused on capacity-building, food, health and education. In recent years, a juvenile justice system has been established; despite some difficulties, its implementation is ongoing.

19. The country's multiethnic composition and the rights of indigenous peoples are both recognized in the Constitution. Of 106 million Mexicans, 10 percent live in indigenous communities and many of them in poverty A variety of programmes are implemented to overcome this situation through the National Commission for the Development of Indigenous Peoples. The 68 indigenous languages are recognized in the 2003 General Act on the Linguistic Rights of Indigenous Peoples, and therefore have the same status as Spanish. The National Institute of Indigenous Languages was created in 2005 to elaborate educational material, promote basic and professional education for educators, and promote the teaching of indigenous languages. Nevertheless, one of the main challenges is achieving full access for indigenous peoples to compulsory, bilingual and intercultural education. The Federal Government is creating Intercultural Universities in several states. Mexico recognized the challenge of respecting indigenous peoples' right of access to justice of and ensures certified defence counsel, interpreters and translators in all lawsuits and proceedings involving indigenous people.

20. Mexico has promoted a foreign policy aimed at protecting the rights of Mexicans living abroad. Mexico has to ensure coherence between the fair treatment claimed for Mexicans living abroad and the 
treatment given to foreign migrants in Mexico. Consequently, in July 2008 undocumented migration was de-criminalized.

21. On the fight against Poverty, Mexico highlighted the Federal Government's launching of the Living Better strategy, in line with the Millennium Development Goals (MDGs). Mexico is achieving these goals and has even set additional ones, as reflected in the current $\mathrm{Na}$ tional Development Plan (NDP).

\section{B. Interactive dialogue and responses by the State under review}

22. During the interactive dialogue, statements were made by 56 delegations. Additional statements which could not be delivered during the interactive dialogue due to time constraints are also posted on the UPR extranet when available.* Numerous delegations thanked Mexico for its comprehensive presentation and for the quality of its national report, which was elaborated in consultation with civil society. Mexico was congratulated for its full cooperation with international human rights mechanisms, particularly its ratification of all relevant human rights instruments, issuance of a standing invitation to special procedures and recognition of the competence of bodies to receive complaints. Its positive contribution to the work of the Human Rights Council and the institution-building process was also particularly welcomed.

23. Brazil welcomed the abolition of the death penalty in 2005. It stressed the significant challenges faced by Mexico, such as equalizing social and regional disparities, adding that a significant part of the Mexican population still lives in poverty, a situation which disproportionally affects indigenous people, the disabled and other vulnerable groups. Brazil recommended that Mexico (a) consider progressively withdrawing its reservations to international human rights instruments; (b) strengthen efforts to fight poverty; and (c) harmonize national and regional legislation in order to avoid discriminatory practices against women and indigenous peoples.

24. Algeria enquired about legal provisions protecting freedom of religion or belief. It recognized Mexico's achievements in reducing poverty but was concerned that most of the poor belong to indigenous com-

* Albania, Australia, Bosnia and Herzegovina, Czech Republic, Greece, Lebanon, Liechtenstein and Slovenia. 
munities. Algeria recommended that Mexico (a) attach particular attention to indigenous communities in its strategies to reduce poverty and to combat extreme poverty; referring to the 2006 conclusions of the Committee on the Rights of the Child (CRC) and of the Committee on Economic, Social and Cultural Rights (CESCR), Algeria recommended that Mexico (b) take effective measures to put an end to domestic violence and abuse of children; it further recommended that Mexico (c) ensure the effective access of all children to education, in particular migrant and indigenous children, and take effective measures to combat their exclusion from the education system, and (d) take all necessary measures to ensure the effective application of the Federal Act to Prevent and Punish Torture.

25. Morocco noted with satisfaction the current review of the Constitution with a view to introducing international human rights standards therein. It welcomed the Federal Government's efforts for economic development, in particular the considerable budget allotted to that end. It recommended that Mexico (a) continue to promote the ratification of the International Convention on the Rights of All Migrant Workers and Members of Their Families (ICRMW); and (b) pursue the reforms initiated to ensure the full enjoyment of human rights and fundamental freedoms to its citizens, in particular the harmonization of domestic legislation with its international commitments.

26. Spain highlighted the creation of the National Human Rights Commission (CNDH) in 1990 and of the NHRP for 2008-2012. It recommended that Mexico (a) complete its institutional efforts to ensure that the international human rights norms it adopts have constitutional status and are applied as supreme law in court proceedings; and (b) harmonize federal and state laws with international instruments, to ensure equal protection and guarantees at federal and state levels. Spain asked whether individuals have effective remedies against possible human rights violations committed by military staff, and whether the internal procedures of the various police forces have adopted the Code of Conduct for Law Enforcement Officials included in the Basic Principles on the Use of Force and Firearms, as recommended by OHCHR-Mexico.

27. Egypt requested that Mexico elaborate on its efforts to promote the rights of migrant workers and people with disabilities at the internal level, and on challenges facing these efforts. Egypt also enquired about the delegation's views with regard to the status of ratification of ICRMW 
and the reasons it perceives for many countries' delay in ratifying this Convention by.

28. Bahrain welcomed the establishment of a national institute for women to evaluate and coordinate government efforts to achieve gender equality, as well as the NHRP. It commended the Government's role in encouraging education through free compulsory primary education; and the efforts made to advance the rights of children and adolescents, including their right to decent life. Bahrain welcomed the measures taken to improve the criminal justice system and requested further information regarding progress and challenges in this regard. It also enquired on Mexico's efforts to establish plans and strategies to create a culture of equality between men and women.

29. Azerbaijan recommended that Mexico: (a) effectively incorporate the provisions of the international human rights instruments into national legislation; (b) investigate the alleged cases of torture and other human rights abuses committed by police, military and security personnel and put an end to the climate of impunity; (c) take effective measures to combat violence and discrimination against women, including cases of murder and disappearances; (d) increase its efforts to improve the whole system with regard to indigenous peoples; (e) investigate the cases of attacks against journalists and human rights defenders; and (f) put more efforts and financial resources into eradicating poverty and high mortality and malnutrition rates, especially in rural areas and among indigenous peoples.

30. Cuba noted that corruption and violence, particularly violence related to drug trafficking and violence against women, are amongst the largest obstacles to the full enjoyment of human rights in Mexico. Poverty reduction and fair redistribution of wealth among the different segments of society and geographical regions are other enormous challenges. Cuba recommended that Mexico (a) investigate and prevent impunity in cases of human rights violations committed by law enforcement officials, throughout the national territory; (b) redouble efforts in combating corruption at all levels; and (c) do everything within its reach to minimize income inequalities between social classes and between geographical regions.

31. Uzbekistan noted treaty bodies' concern about the practice of arbitrary detention in Mexico and the excessive use of force by law enforcement officials during disturbances in some cities in 2004 and 2006. 
According to United Nations bodies, migrants who are expelled from Mexico face difficulties in accessing justice. Uzbekistan recommended that Mexico (a) take the necessary measures to prevent the use of torture, including by ensuring timely, effective and impartial investigations of all allegations concerning torture; (b) investigate all allegations of human rights violations, particularly in relation to persons detained during police operations, and ensure that perpetrators are properly brought to justice and punished; and (c) take all necessary measures to protect the rights of migrant workers and members of their families, particularly by ensuring their access to justice.

32. Belarus noted the NHRP and the independent monitoring by $\mathrm{CNDH}$ of the human rights situation . Belarus, noting the efforts already made, recommended that Mexico (a) continue developing and ensuring an effective policy in combating organized crime and corruption. Belarus stressed the importance given by Mexico to ensuring the rights of women and children. The level of access to education is being increased at all levels. Belarus recommended that Mexico (b) continue efforts to eradicate sexual exploitation of children. While welcoming the adoption of a law on the prevention of trafficking in persons, Belarus recommended that Mexico (c) take measures to criminalize trafficking in persons in all parts of the federation and strengthen the resource basis for the protection of victims.

33. Portugal noted that the definition of organized crime enables members of social movements to be accused of belonging to organized crime groups, and recommended that Mexico (a) enact a definition of organized crime consistent with the United Nations Convention against Transnational Organized Crime. Noting that torture is not yet totally prevented throughout the country, Portugal recommended (b) the effective application of the Federal Act to Prevent and Punish Torture, and that (c) Mexico follow up on the recommendations of the Committee against Torture (CAT) and OHCHR to empower civil courts to try offences against human rights, in particular torture and cruel, inhuman or degrading treatment committed by military personnel, even when it is claimed that they were service-related. Concerned at the reported abuses and human rights violations by law enforcement officials in prisons, Portugal recommended that Mexico (d) fully investigate such abuses and human rights violations and ensure that perpetrators are duly punished. Portugal welcomed the agreement signed with the International Committee of the 
Red Cross (ICRC) and recommended that Mexico (e) continue to develop measures to improve the situation in prisons and the training of prison officials.

34. Bolivia noted that in 2008 Mexico introduced a strategy to combat economic inequality and poverty. It enquired about actions taken on this issue regarding indigenous peoples, and whether the principles set out in the Declaration on the Rights of Indigenous Peoples are being incorporated in domestic law. Bolivia recommended that Mexico (a) adopt the necessary measures to harmonize federal and state laws with international human rights instruments it ratified; (b) adopt necessary measures to eradicate impunity for human rights violations, particularly against women and indigenous population; and (c) adopt necessary measures to ensure the right of indigenous peoples to be consulted, in accordance with the commitments undertaken by ratifying ILO Convention No. 169 concerning Indigenous and Tribal Peoples.

35. Ukraine welcomed the strengthening of legislation combating discrimination and promoting gender equality. Noting that the serious concern about murders of women remains unresolved, Ukraine recommended ensuring effective investigation and punishment of these crimes and adopting additional measures to combat this phenomenon and raise awareness about this threat. Civic mechanisms to monitor government action to counter public insecurity and organized crime have been set up, as well mechanisms for investigation and punishment of alleged human rights violations by police officials. Ukraine enquired whether Mexico evaluated the efficiency of these mechanisms and their impact on the protection of human rights in the context of police activities.

36. Indonesia commended Mexico for promoting the rights of women and indigenous people through legislative reform and for its national strategies on human rights, including the NHRP. Indonesia noted the concerns expressed by the Committee on the Elimination of Discrimination against Women (CEDAW) concerning widespread and systematic violence against women and asked whether Mexico intends to adopt any new policies or measures in the near future to address this issue. Indonesia recommended that Mexico further strengthen its endeavours to eradicate and address cases of violence against women and child abuse.

37. Pakistan underlined that Mexico has amended its Constitution to incorporate international human rights standards, recognize the rights of indigenous peoples, prohibit all forms of discrimination, reform the juve- 
nile justice system, assure the right to information, and reform the public security and criminal justice system. Pakistan welcomed the NHRP and the special human rights units created in various government entities. It recommended that Mexico (a) address discrimination and violence against women through education and specific legislation, both in the public and the private sectors; (b) develop affirmative programmes to uplift the living standards of women and ensure their presence in decision-making positions; (c) ensure the full realization of the rights of migrants on its territory by enacting legislation and providing training to concerned officials; (d) address the problems of street children by providing them State protection and vocational training; (e) take firm action to eliminate corruption and impunity in the judicial, security and executive branches; (f) invite the relevant special rapporteurs to visit Mexico and make necessary recommendations to uplift the lot of indigenous communities, in line with its commitments and relevant international instruments.

38. The Netherlands was pleased with the 2008 reform of the judiciary system and the significant efforts to fight organized crime. It recommended that Mexico (a) bring state laws and federal legislation into line with the framework established by the General Act on Women's Access to a Life Free of Violence. Concerned that journalists continue to be victims of abuses and grave human rights violations, it recommended that Mexico (b) create the proper legal framework that gives the Special Prosecutor's Office for Crimes against Journalists independence to investigate and indict perpetrators. The Netherlands noted a concentration of control of the media in the hands of few individuals or groups of businesses, and recommended that Mexico (c) review its legislation governing radio, television and communication and followup on the Supreme Court's order to submit a legislative initiative for a new legal framework permitting diversity in the media.

39. Sweden remained concerned about the reported widespread and systematic violence against women, including cases of disappearances and domestic violence. It recommended that Mexico (a) continue efforts and implement all measures necessary with a view to tackling the problem of violence against women. Sweden expressed concern about the estimation of the CNDH that 99 percent of all crimes in Mexico are not resolved, and noted the high number of unresolved killings and abuses of journalists. Sweden recommended that Mexico (b) continue efforts and take all 
measures necessary to put an end to impunity, also with regard to crimes against journalists. Referred to concerns expressed by the Committee on the Rights of the Child in 2006 with regard to the wide use of corporal punishment within families, schools and other institutions, Sweden recommended that Mexico (c) take measures to ensure that children are fully protected from corporal punishment and other forms of violence or exploitation.

40. The United Kingdom noted that most rights are generally respected in practice. Noting that the NHRP is directed at federal institutions only, it asked that Mexico provide a commitment to ensure thorough implementation of its obligations at state and municipal levels. The United Kingdom noted the concern of the Committee against Torture regarding the use of torture in criminal investigations, and urged all cases of torture committed against civilians by military personnel to be tried in civilian courts. It stressed that Mexico has been named amongst the top three most dangerous countries for journalists and supported the two international NGO missions' findings of 2008 that the government needs to give priority to tackling this. It recommended that Mexico (a) make a concerted effort to tackle impunity nationwide; (b) take further steps to address discrimination against, and protect and provide assistance to women and vulnerable groups including children, minorities and indigenous peoples; (c) publicly recognize the important role of human rights defenders and NGOs in the protection of human rights in Mexico, and (d) put into place more effective measures to tackle violence towards journalists.

41. Austria welcomed the adoption of the NHRP and the cooperation with OHCHR-Mexico. It recommended that Mexico (a) further strengthen the mechanisms for the effective implementation of the NHRP at all levels of government. Citing treaty bodies' concerns about excessive use of force by the police in San Salvador Atenco and Oaxaca, Austria stated that perpetrators seem to benefit from a culture of impunity. It recommended that Mexico (b) ensure that the reform of the public security and criminal justice system is being implemented quickly in order to ensure that human rights violations by the security forces are systematically investigated, perpetrators brought to justice and victims compensated. Noting that journalists face serious threats, Austria enquired whether the new bill in this regard was perceived as being effective enough in punishing such acts in practice. It recommended that Mexico (c) provide ad- 
equate funding for investigations, victim-support programmes for affected women and special training for the police to sensitize them to the problem of violence against women.

42. Viet Nam commended Mexico for its enormous efforts in solving difficulties in the areas of poverty alleviation, health protection and equality between men and women. Mexico has intensified efforts in combating crimes, corruption and torture, and in protecting justice and social security. Viet Nam appreciated the adoption of the National Programme for the Promotion of Human Rights among Police and Prison Officials and the NHRP. It recommended that Mexico continue its efforts and take further steps to ensure the rights to food and health for its people, particularly for the vulnerable groups living in extreme poverty, including indigenous people.

43. Canada recommended that Mexico (a) promote the effective domestic implementation of its international human rights obligations through the adoption of policies, laws and other measures at the federal and state levels and through regular consultations with key stakeholders, including states, civil society organizations and others. It recommended that Mexico (b) promote the implementation of reforms of the police and the judiciary, which it welcomed. Expressing concern about alleged human rights abuses committed while combating drug cartels, Canada recommended that Mexico (c) fully investigate all allegations of human rights violations committed by elements of the military and security forces, including the adoption of recommendations made by the National Human Rights Commission. It noted the important progress to achieve the MDGs and expressed concern about continued widespread marginalization and poverty, particularly in the southern states. Welcoming the intensified cooperation, internally and bilaterally, to advance progress of indigenous communities, Canada recommended that Mexico (d) continue to strengthen programmes aimed at creating growth and employment and combating poverty.

44. Belgium noted the persistence of a climate of impunity, particularly with regard to systematic violations of the human rights of women and human rights defenders. It regretted the decision taken to abolish the Special Prosecutor's office for past-political and social movements, mandated to investigate allegations of human rights violations committed in the past. Belgium enquired inter alia about the positive effects in combating impunity of the 2008 National Agreement on Security, Justice and 
Legality, and about the follow-up given to the various cases addressed by the Special Prosecutor's office that have been transferred to the office of the General Prosecutor in 2006. Belgium recommended that (a) combating impunity be one of the Government's priorities, (b) structural measures be set up to address systematically violence and violation of fundamental rights, of which women and human rights defenders are victims, and that Mexico (c) re-establish the Special Prosecutor's Office for Past-Political and Social Movements or create a similar office, which would be a strong signal towards combating impunity for victims and their families.

45. Germany asked when the Mexican army will completely withdraw from public security tasks. It recommended that Mexico (a) increase the effectiveness of the "precautionary measures" to protect human rights defenders and step up investigations on reports of killings, threats, attacks and acts of intimidation of human rights defenders in order to bring the perpetrators to justice; (b) strengthen the publicity, the implementation and the monitoring of NHRP, and step-up dialogue with civil society in this regard; and (c) strengthen the rights of journalists and free media; cases of violence and threats against journalists must be investigated, and the state and the municipal governments should fulfil their responsibility to protect a free media.

46. Chile welcomed the commitments to combat impunity and the recent reform of the public security and criminal justice system. It recommended that (a) sufficient financial and human resources be allocated for the implementation of this new system, including adequate dissemination of information for users as well as the respective training of judges and lawyers. While recognizing efforts made to protect women's rights Chile recommended (b) adopting the measures necessary to advance towards harmonizing legislation at all levels and eliminating all discriminatory elements still present in some state laws. Taking into account the report the Special Rapporteur on violence against women, Chile recommended that (c) the implementation of the General Act for Women's Access to a Life Free of Violence be undertaken by all relevant authorities, at the federal, state and municipal levels, including in the prevention and eradication of violence against women, as well as care for victims.

47. Turkey recommended that Mexico (a) speed up efforts to harmonize federal and state laws with human rights treaties and ensure their effec- 
tive implementation at all levels. While welcoming the National Agreement on Security, Justice and Legality, Turkey recommended that Mexico (b) continue the public security and justice reforms and fight against organized crime through effective policies. Concerned about violence against women, Turkey further recommended (c) the effective implementation of the Comprehensive Programme to Prevent, Address, Punish and Eliminate Violence against Women across the country. Turkey requested information about the Migrant Protection Beta Groups and enquired whether the Living Better strategy of 2008 and Make Yourself at Home programme include targeted measures for migrant and indigenous populations most affected by poverty.

48. Nigeria noted that, notwithstanding progress on human rights, Mexico is still faced with major challenges in: implementing justice system reforms; guaranteeing the rights to individual security; effectively implementing international human rights standards at various levels, including full alignment of state and federal law and strengthening of institutions; and the effective application of those standards in court rulings and sentences. Nigeria encouraged Mexico to continue its extensive reforms and improvement of human rights policies and infrastructure to address the persistence of institutional shortcomings and weaknesses, tackle organized crime, transform the justice administration system and develop an integrated agenda for human rights and public security and a development agenda towards poverty eradication.

49. New Zealand, welcoming significant transformations in Mexico's institutions, noted that several states continue to have discriminatory legislation. At local level, there can be limited understanding of legislative requirements to take into account the particular needs of indigenous peoples. It recommended that Mexico (a) conduct a time-bound review of legislation at state level which discriminates against women, and (b) commit to promptly repealing such legislation, with priority attention paid to family law that results in real or de facto discrimination against women and girls, and to legislation that prevents women's access to justice, particularly in respect of the reporting and prosecution of family violence; (c) that the Federal Government provide guidance to all states on the adoption of practical measures to ensure the implementation of these legislative changes at the local level; (d) that the Federal Government strengthen its efforts to raise awareness of indigenous rights, language and customs, by providing guidance and training to military 
and local officials, including the police, judiciary, and members of the legal community, particularly in rural areas. Recognizing the challenges the Government faces in combating organized crime, it recommended (e) that Mexico recognize the centrality of human rights and the rule of law in its approach to improving public security; and specifically put an end to the "arraigo" system as soon as possible and ensure that the rights of detainees are respected.

50. Tunisia noted Mexico's great efforts to promote and safeguard human rights, the establishment of the Government's Human Rights Policy Commission, the CNDH set up in accordance with the Paris Principles, and the 32 human rights institutions within federal entities. Tunisia noted Mexico's commitment to equality of opportunities and rights to eradicate poverty. It requested further information on the Living Better programme for strengthening mechanisms and actions to combat poverty.

51. Norway recommended (a) that Mexico establish an effective and inclusive process to follow-up on UPR recommendations. It expressed concern about the vulnerable situation of human rights defenders, and noted the High Commissioner for Human Rights' views that unsolved killings and abuses of journalists contribute to a climate that restricts free speech. Norway recommended that (b) crimes and violations against human rights defenders, journalists and lawyers be effectively investigated and prosecuted, and that those responsible be punished; complaints of threats, harassment and intimidation of human right defenders, journalists and lawyers must receive a prompt response and adequate measures for their safety should be taken; (b) Mexico improve the existing protection programme, including through adopting effective and comprehensive prevention strategies, at central and local levels, to prevent attacks and protect the life and physical integrity of human rights defenders and journalists, and that such programmes be backed by a strong political commitment and provided with adequate resources; and (c) NGOs working on press freedom be invited to a constructive dialogue on how Mexico can stop the violence against journalists and ensure press freedom.

52. China stressed that Mexico faces difficulties in its economic and social development and noted efforts to develop the economy and eliminate poverty and improve people's standard of living and social security, and the progress made regarding environmental protection and the rights to education, health and culture. China asked how Mexico has integrated 
MDGs in its national development plan or strategy, and what challenges it has faced in this regard. While noting that Mexico was one of the first countries to adopt special programmes to help people living in extreme poverty, China asked whether the number of affected people was more than halved in ten years and whether Mexico has any experience to share in this regard.

53. Finland welcomed the abolition of death penalty in 2005 and Mexico's commitment to push forward important reform processes in the justice sector, stressing the lack of access to justice, particularly in states and for indigenous peoples. Finland recommended (a) that the human rights of indigenous peoples be placed high on the agenda when addressing questions of impunity and that access to justice be improved for indigenous peoples, including by strengthening public defence for indigenous peoples and providing better translation services. It asked how the law on the protection of women from violence has proceeded in states, and how the Federal Government has been able to ensure its proper implementation. It recommended that Mexico (b) bolster the Special Prosecutor's Office on Violent Crime against Women and Human Trafficking so that it may better investigate cases, and that cases falling within local jurisdiction be investigated with due diligence.

54. Ireland recommended that Mexico (a) assist and encourage the Federal state's authorities to implement the General Act on Women's Access to a Life Free of Violence as a matter of urgency and, where the General Act has been incorporated in states' legislation, ensure that appropriate regulations are elaborated to ensure its effective implementation. Ireland expressed concern at the continued use of military courts to investigate and try military abuses of human rights and noted that the military has taken on a policing role in many states. It recommended (b) reviewing the Code of Military Justice with a view to extending the jurisdiction of civil courts in cases involving violations of human rights by the military, in order to align more closely with international human rights obligations. Concerned at the high numbers of prisoners who have yet to be sentenced, Ireland recommended (c) devoting sufficient resources to the criminal justice and prison systems in an effort to reduce the sentencing backlog. Stressing that the practice of "arraigo" could be characterized as a form of arbitrary detention, it recommended (d) that Mexico evaluate its use. 
55. Italy highlighted Mexico's efforts to reform the judicial system to tackle organized crime and put an end to impunity. Italy recommended (a) that the ongoing reforms in the judicial system be conducted in strict conformity with international human rights standards and that civil society be adequately involved in this process; (b) that measures against corruption and police abuses be strengthened; and (c) that human rights aspects be included in all training programmes and be extended to all police units. Italy enquired about the results of the investigations conducted so far in the murder of women in Ciudad Juárez. It recommended that (d) these crimes be fully clarified, that those responsible and their accomplices, including civil servants who might have not conducted investigations, be brought to justice and that effective measures be taken to prevent such crimes in Ciudad Juárez.

56. France enquired about envisaged measures to ensure access to education to all children and to eradicate child labour, and about the state of the implementation of recommendations of the Special Rapporteur on the sale of children, child prostitution and child pornography in 2008. Noting the regular reports of pressure on the media and threats against journalists, it recommended that Mexico (a) take measures to guarantee freedom of demonstration and ensure protection of demonstrators; (b) take necessary measures to combat practices of torture and illtreatment by security forces in prisons, as noted by special rapporteurs, and to combat impunity in this regard; and (c) improve living conditions in prisons.

57. Palestine welcomed the creation of the General Directorate of Human Rights in the Ministry of Defence and the measures taken to compensate violations of human rights. Palestine noted that implementing the justice system reform, guaranteeing the right to security of the person, and effectively implementing international human rights standards at various levels of society, remained challenges for Mexico. Palestine recommended that Mexico (a) continue working towards the professionalization and the modernization of the judicial system in all areas, including law enforcement and administration of justice.

58. The Republic of Korea noted the multifaceted challenges faced by the Mexican people. It recommended that Mexico consider granting jurisdiction to its civil authorities and courts over the acts of military personnel performing law enforcement functions, adding that if the military involvement in combating organized crimes is necessary, the expanded role of the military must be counterbalanced by measures to reinforce the 
protection of human rights. It encouraged Mexico to continue to strategically mainstream gender perspective and minority rights into all its anti-poverty combat programmes.

59. India noted with appreciation: the full incorporation of the rights enumerated in the Mexican Constitution into the constitutions of the 32 federal entities; the adoption of the NHRP; the stated high level of compliance by the Federal Government with the recommendations of the $\mathrm{CNDH}$; efforts made to reduce poverty; high levels of achievement of various MDGs; the country's specific slum upgrading and prevention policies; its acknowledgement of the socioeconomic deficit among indigenous peoples; and the high allocation of resources to remedy this situation. India requested more information about the concerns expressed regarding the requirement made sometimes to women to present non-pregnancy certificates to employers and the general public perception of a high level of impunity for nearly all types of crimes committed in the country, as well as about local repatriation arrangements for migrants from neighbouring countries.

60. Argentina enquired about measures envisaged to eliminate gender violence and discrimination against women. Citing the observations of CESCR, it enquired about amendments made to labour law to eliminate restrictions on trade union rights. Argentina noted reports of discrimination against indigenous peoples, adding that the 2001 constitutional reform only included limited protection of the rights of indigenous peoples. It recommended that Mexico adopt appropriate legislation in full conformity with international standards on the rights of indigenous peoples.

61. The Holy See expressed concern about the killing of women. It was concerned that part of the population lacks access to basic needs such as food, water, housing, sanitation and health care, and (a) recommended that Mexico continue efforts to eradicate extreme poverty. Stressing the relatively high rate of maternal deaths, it (b) recommended that the Government redouble efforts to reduce the number of maternal deaths, especially among indigenous women, by training birth attendants and establishing more obstetric clinics. Noting the concern of the Special Rapporteur on the human rights of migrants about reports of child labour, the situation of unaccompanied minors, and violence against migrant women, which seemed to be widespread, it requested information on measures taken to address this problem. 
62. Bangladesh was pleased to note that human rights feature prominently in the ongoing constitutional reform. Bangladesh recommended that (a) the allegation of systematic and excessive use of force and torture by law enforcement agencies be seriously dealt with to end the culture of impunity; (b) the primacy of the civil legal system prevail over military judicial process across the entire territory; (c) incidences of domestic violence and femicide be tackled through a multi-pronged approach, including effective legal measures and social awareness programmes; (d) the prevalence of corporal punishment on children be curbed in keeping with Mexico's international advocacy against such offences; (e) measures be undertaken to redress marginalization of indigenous and migrant populations in line with the prominent role of Mexico on the international scene, and (f) the safety and security of journalists and media personnel in discharging their professional responsibilities be guaranteed.

63. Responding to questions, the delegation explained that, pursuant to the Constitution, human rights violations are investigated through jurisdictional and non-jurisdictional means. The latter include national and international human rights organs, which gather all reliable information to determine if a human rights violation was committed by military personnel. The justice system includes the Military Prosecutor-General and courts, which determine whether conduct constitutes an offence and apply the corresponding sanctions and reparations. In addition, the Army's Inspector-and Controller-General carries out administrative procedures to determine if any infractions were committed within the scope of its mandate. In the past two years there have been 27 instances of proceedings against a total of 40 members of the military on charges related to human rights abuses. The armed forces maintain close cooperation with national and international human rights mechanisms and NGOs.

64. The delegation stressed that military jurisdiction exists in most countries, and that the Constitution establishes military courts for offences against military discipline, limiting their scope to the military.

65. The 2008 constitutional reforms provided for a new police model that regulates and certifies police personnel, establishes coordination mechanisms between the three levels of government, enables corruption to be combated through strict controls, the establishment of criminal databases, and the participation of society in the prevention of crime through citizen observatories. The Ministry of Public Security estab- 
lished an agreement with ICRC to develop protocols on the legitimate use of force based on principles of proportionality, necessity and rationality. The National Programme for the Promotion of Human Rights among Police and Prison Offficials at the three levels of government had reached 30 percent of police personnel nationwide, having been adopted based on the Code of Conduct for Law Enforcement Officials and the United Nations Basic Principles on the Use of Force and Firearms by Law Enforcement Officials. A national support network for crime victims, created in 2008, provides services including legal advice, medical and psychological care and reparation, and keeps minors' identity secret, even in cases involving the gravest crimes.

66. Denmark noted the improvement of the general human rights situation despite challenges. It noted with concern credible reports of ongoing torture and ill-treatment by police officers and of continuing impunity, and that severe discrepancies still seem to occur in legal proceedings involving indigenous people. The safety of journalists also remains a concern. Denmark recommended (a) that Mexico step up efforts to halt torture and ill-treatment, eradicate impunity for such acts and ensure that alleged perpetrators are brought to justice; (b) that indigenous peoples and other marginalized communities affected by planed economic or development projects are adequately and fairly consulted; and (c) that Mexico step up efforts to ensure the safety of journalists and that investigation of attacks on voices for freedom of expression become a federal issue.

67. Switzerland welcomed the incorporation of international human rights standards in the Constitution, the NDP and the NHRP, but noted that this has not yet achieved all the expected results. It recommended (a) that federal authorities ensure the concrete implementation of international human rights standards at all State levels. Stating that the practice of "arraigo" seems to amount to arbitrary detention, it recommended that Mexico (b) abolish this practice. Aware of the challenges in combating organized crime and drug trafficking, Switzerland considered that the current strategy of using armed forces might lead to abuses and recommended that Mexico (c) ensure proper training on human rights to members of its armed forces, the police, and prison staff and court staff.

68. Jordan commended the consolidation of the regulatory and institutional frameworks to enhance the promotion and protection of human rights. These efforts include the full incorporation of these rights into the 
constitutions of Mexico's 32 federal entities. Jordan noted with appreciation the establishment of the NDP. It requested further information on the 2008 Alliance for Quality in Education programme.

69. Honduras noted with satisfaction efforts to improve the situation of migrants. Honduras noted Mexico's fight against organized crime and recommended (a) that the Government's policies and strategies be strengthened and shared with countries of the region to combat this crime at the regional level and (b) that regional workshops be continued to share experience for the transfer of knowledge in systems of public security and criminal justice. Honduras recommended (c) that the system of primary health care continues to be extended and strengthened and that Mexico continue to improve the quality of such services with particular attention to indigenous peoples. Honduras noted with satisfaction that a food programme is included within poverty-reduction strategies and recommended (d) that measures be taken to reduce the problem of extreme poverty affecting the population, in particular indigenous peoples' rights. It recommended that Mexico (e) disseminate the report presented by the Mexican Government, as well as the observations and final recommendations resulting from the UPR, at the national level.

70. Japan congratulated Mexico for pledging to implement recommendations resulting from the UPR. Japan recommended that Mexico further strengthen and promote efforts to prohibit torture and impunity. Japan applauded progress made in promoting the rights and protecting the languages and cultures of indigenous peoples. It noted that imbalances in employment, education, living standards, and access to justice remain between indigenous and non-indigenous people and recommended more concrete measures be taken to eliminate employment and wage gaps, to increase school enrolment rates of indigenous children, and to review the justice system. It also recommended that the Comprehensive Programme to Prevent, Address, Punish and Eliminate Violence against Women developed under the General Act on Women's Access to a Life Free from Violence be implemented as soon as possible.

71. Guatemala enquired about strategies used to consolidate the reform process relating to human rights, and about programmes put in place for the reinsertion of migrants returning to the country. It recommended that Mexico (a) harmonize its internal legal framework at all levels of government, towards the effective judicial implementation of all international human rights norms; (b) give priority to the recommenda- 
tions made by the Special Rapporteur on the human rights of migrants; (c) ensure that migrants have access to an effective remedy before a competent authority for the protection of their rights, and prosecute and punish civil servants responsible for acts of ill-treatment and offences against migrants; (d) continue enhancing the working conditions of temporary agricultural labourers and strengthen the work of labour inspection authorities; and (e) continue addressing the recommendations made by the Special Rapporteur on the situation of human rights and fundamental freedoms of indigenous people.

72. The Philippines supported the priority given to families in extreme poverty and viewed the establishment of special human rights units in federal ministries as a best practice. It recommended that Mexico (a) strengthen measures to protect and provide assistance to victims of human trafficking, with special emphasis on children victims; (b) pay special attention to the situation of indigenous people in its poverty-eradication programmes; and (c) seek to improve the enrolment rate of girls in primary and secondary schools. It asked how Mexico engages migrant and diaspora communities abroad into contributing to national development efforts and programmes.

73. Colombia understood the difficulties faced by Mexico in combating impunity, corruption, kidnapping, drug trafficking and all forms of violence. Colombia commended in particular efforts to elucidate 275 cases of enforced disappearances noted by $\mathrm{CNDH}$ and urged continuing investigations and trials to provide justice and reparation for victims. Colombia recommended that Mexico continue promoting the bill on enforced disappearances. Welcoming the commitment to clarify the murder and disappearance of women in Ciudad Juárez, Columbia enquired about progress made by CNDH to prevent and eradicate violence against women in the town.

74. The Russian Federation considered that Mexico had made considerable changes to its institutions. It recommended (a) that Mexico mandate civilian courts with the jurisdiction to prosecute cases of human rights violations committed by members of armed forces when they carry out law enforcement functions. According to NGOs, some mass media sources are concentrated in the hands of a few influential families, and according to the Supreme Court itself amendments introduced by the Government in the law on radio and television and the law on telecommunications run contrary to freedom of expression and opinion. The 
Russian Federation recommended (b) that legal reforms be undertaken to ensure democratization of the media in the country.

75. Peru acknowledged the NHRP, as well as programmes to reduce poverty. It recommended that Mexico (a) review the relevant legal provisions to ensure that all offences committed against human rights by military forces may also be submitted to civil courts; (b) provide greater guarantees and security to journalists and mass media professionals, in particular those that investigate and report cases of drug trafficking and corruption; and (c) carry out a prompt implementation of the judicial reform, in order to ensure that complaints in cases of torture, arbitrary detentions and forced disappearances are exhaustively investigated.

76. The Syrian Arab Republic appreciated Mexico's clear commitment to protect human rights despite challenges, especially in the field of poverty alleviation, education for all and the inequalities faced by indigenous peoples. The Syrian Arab Republic recommended that Mexico pursue its plans to address prostitution, pornography and trafficking of children and adolescents for the purpose of sexual exploitation.

77. Uruguay noted that Mexico is close to meeting the MDGs. It was pleased to see that public security and judicial authorities have taken action against murder of women in Ciudad Juárez. Uruguay recommended that Mexico (a) continue efforts to harmonize federal and state legislation to ensure the full application of international human rights norms; for example, extend to other federative entities, the categorization of the crime of "forced disappearance" and the full compensation mechanism for victims and members of their families. It also recommended that (b) military courts be abolished. Uruguay believed that it is not right that special units of the armed forces be tasked with police and public security, even when this is done to combat organized crime.

78. Saudi Arabia noted that Mexico's Constitution refers to fundamental rights and that a number of governmental and non-governmental bodies monitor the implementation of human rights. Saudi Arabia enquired about programmes implemented to give effect to the right to health and about the role played by the public security framework. Saudi Arabia recommended that Mexico (a) continue efforts to implement the right to education and health and strengthen the national programme for those rights.

79. Panama welcomed the creation of a national mechanism to prevent torture and the establishment of an agreement for the establishment 
of OHCHR-Mexico. It noted the approval in Congress of a law to prevent and punish human trafficking It recommended that Mexico (a) increase dialogue and consultations with civil-society organizations in the design of follow-up measures and implementation of the UPR towards strengthening the impact of the human rights policies, as set out in $\mathrm{Hu}-$ man Rights Council resolution $5 / 1$; (b) persevere in efforts to build a truly inclusive democracy by fully recognizing the rights of indigenous peoples; (c) maintain its priority to end impunity for perpetrators of all forms of acts of violence against women, whatever their social condition, and give more information on progress to prevent such violations.

80. Malaysia commended Mexico for the incorporation of a gender perspective in the NDP and the establishment of a dialogue process involving the national Human Rights Policy Commission and civil society. Mexico's close cooperation with OHCHR and the hosting of the ICRC regional office were noted. Malaysia commended efforts to combat organized crime and requested further information on the reforms to the public security and criminal justice system, in particular the establishment of the accusatory criminal trial system and the practice of amparo. Malaysia recommended that Mexico (a) continue efforts aimed at providing adequate financing for housing to the poorest segments of the population; and (b) fully implement the Rural Food Support and Supply programme, the Social Milk Programme, the Living Better Food Supplement programme and the Comprehensive Food Aid Strategy, with a view to meeting the food requirements of the must vulnerable sections of society.

81. Ecuador requested further information on the situation of migrant workers, in particular undocumented migrants, taking into consideration the concerns of the Special Rapporteur on the human rights of migrants and of the Committee on the Protection of the Rights of All Migrant Workers and Members of Their Families. It noted that the High Commissioner for Human Rights positively assessed Mexico's international efforts in support of the rights of migrant workers.

82. Responding to questions, Mexico said that domestic violence is a ground for divorce in all states' civil codes and is an offence in 29 states. Mexico will continue harmonizing legislation throughout the country. Mexico's commitment to combat gender violence is also reflected in its support for the establishment of regional mechanisms for the protection of women. Following recommendations from CEDAW, Mexico promulgated the General Act on Equality between Women and Men. The 
Government's policy on gender equality is coordinated by the National Institute for Women (Inmujeres).

83. Regarding murders of women in Ciudad Juárez, Mexico stressed that the Prosecutor's Office of the state of Chihuahua is conducting investigations with highly trained staff. Two crime laboratories have been set up in Ciudad Juárez and one in the city of Chihuahua to facilitate identification of the victims through genetic methods. Of the cases, 45 per cent have been resolved, 16 per cent are pending and 33 per cent remain under investigation.

84. Mexico's policy on the rights of the child is based on the interrelatedness of all human rights and aims at ensuring durable solutions. This approach involves a high degree of cooperation between the different branches of the Government, cooperation that is reflected in the policies concerning migrant children.

85. The delegation expressed its deep concern with regard to child labour, mentioning that 3.6 million children aged between 5 and 15 are working in various sectors in Mexico. It stressed that the Government's policies and programmes have benefited more than 300,000 children and have helped to reduce cases of child labour by 17 per cent.

86. The indigenous population has the same rights as all other members of the nation. According to the Mexican Constitution, indigenous peoples also enjoy specific rights based on their cultural differences.

87. The National Programme for the Development of Indigenous Peoples contains specific goals reflecting the Government's aims in overcoming the social, environmental and development difficulties of indigenous peoples.

88. The delegation recalled that, following the constitutional reform in 2001, the collective rights of indigenous peoples were recognized, particularly the rights to self-determination, autonomy as well as access to justice.

89. Bilingual education has been provided to indigenous children since the 1970's. The delegation also noted that the United Nations Declaration on the Rights of Indigenous Peoples has been translated into 20 languages.

90. In conclusion, the delegation stated that Mexico has passed from having 64 million inhabitants, or 64 per cent of the population below the poverty line in 1996, to 43 per cent nowadays. Extreme poverty was reduced from 37 million to 14 million during the same period. Mexico's 
commitment to social policy was reflected both in terms of the resources devoted to this, as well as the strategy implemented. The federal budget dedicated to social policy in 2000 was 8.3 per cent of GDP and 40 per cent of public expenditure. For 2008, allocations increased to 9.7 per cent of GDP, representing 44 per cent of public expenditure. The "Living Better" social policy, oriented towards those who need it most, has three components, namely, development of basic capacities, actions to increase nutrition and infrastructure projects. The Popular Insurance scheme guarantees health and medicines to persons not covered by traditional social-security institutions. Mexico seeks universal coverage, and the establishment of medical insurance for all children, by 2010 .

91. The Mexican Government is engaged in a constant struggle to raise economic, social, cultural and educational standards, as well as overcoming poverty and violence. Mexico acknowledged the numerous challenges the country faces and indicated that there is a generalized will of all of those in government to advance in the promotion and protection of human rights.

92. The Government is open to criticism and is willing to learn from it. The delegation thanked the Working Group for its recommendations and expressed its total commitment to finding the best means of making progress regarding them. Mexico is prepared to respond to the international community in all matters falling within its responsibility.

\section{CONCLUSIONS AND/OR RECOMMENDATIONS}

93. The recommendations listed below have been examined by Mexico and enjoy the support of Mexico.

1. Continue to promote the ratification of the International Convention on the Rights of Migrant Workers and Member of Their Families (Morocco).

2. Consider progressively withdrawing its reservations to international human rights instruments (Brazil).

3. Pursue with reforms initiated to ensure the full enjoyment of human rights and fundamental freedoms to its citizens, in particular the harmonization of domestic legislation with its international commitments (Morocco). 
4. Complete its institutional efforts ensuring that international human rights norms adopted by Mexico have constitutional status and are applied as supreme law in courts proceedings (Spain).

5. Effectively incorporate the provisions of the international human rights instruments into national legislation (Azerbaijan).

6. Harmonize federal and state laws with international human rights instruments (Bolivia, Guatemala, Spain, Turkey, Uruguay), in order to ensure their effective implementation (Turkey), and equal protection and guarantees (Spain), at federal and state levels (Spain, Turkey).

7. Ensure concrete implementation of international human rights standards at all levels (Canada, Switzerland), through the adoption of policies, laws and other measures at the federal and state levels and through regular consultations with key stakeholders, including states, civil society organizations and others (Canada).

8. Harmonize national and regional legislation in order to avoid discriminatory practices against women and indigenous peoples (Brazil) and eliminate all discriminatory elements still present in some state laws (Chile).

9. Further strengthen the mechanisms for the effective implementation of the National Human Rights Programme at all levels of government (Austria), in particular strengthen the publicity, implementation and monitoring of the Programme and step-up dialogue with civil society in this regard (Germany).

10. Do everything within its reach to minimize income inequalities between different social classes and geographical regions (Cuba).

11. Take further steps to address discrimination against, protect and provide assistance to women and vulnerable groups including children, minorities and indigenous peoples (United Kingdom).

12. Address discrimination and violence against women through education and specific legislation both in the public and private sectors; and develop affirmative programmes to uplift the living standards of women and ensure their presence in decision-making positions (Pakistan).

13. Conduct a time-bound review of legislation at state level which discriminates against women; commit to promptly repealing such legislation, with priority attention paid to family law that results in real or de facto discrimination against women and girls, and to legislation that prevents women's access to justice, particularly in respect of the reporting 
and prosecution of family violence; and from the federal level, provide guidance to all states on the adoption of practical measures to ensure the implementation of these legislative changes at the local level (New Zealand).

14. Effectively implement across the country (Turkey) and as soon as possible (Japan) the Comprehensive Program to Prevent, Address, Punish and Eliminate Violence against Women (Japan, Turkey).

15. Bring state laws and federal legislation in line with the framework established by the General Law for Women's Access to a Life Free of Violence (Netherlands); undertake the Law's implementation by all relevant authorities, at the federal, state and municipal levels, including in the prevention and eradication of violence against women, as well as care for victims (Chile); and assist and encourage the Federal state's authorities to implement it as a matter of urgency, and where it has been incorporated in states' legislation, ensure that appropriate regulations are elaborated to ensure its effective implementation (Ireland).

16. Continue efforts to eradicate and address cases of violence against women (Indonesia, Sweden), domestic violence (Algeria) and child abuse (Algeria, Indonesia).

17. Take effective measures to combat violence and discrimination against women, including cases of murder and disappearances (Azerbaijan).

18. Maintain its priority to end impunity for perpetrators of all forms of acts of violence against women, whatever their social condition; give more information on progress to prevent such violations (Panama); and bolster the Office of the Federal Special Prosecutor on violence against women so that it may better investigate cases, and that cases falling within local jurisdiction be investigated with due diligence (Finland).

19. Ensure effective investigation and punishment of the crimes of murder of women, and adopt additional measures to combat this phenomenon and raise awareness about such threat (Ukraine).

20. Ensure that murder of women in Ciudad Juarez are fully clarified, that those responsible and their accomplices, including civil servants who might have not conducted investigations, are brought to justice and that effective measures are taken to prevent such crimes in Ciudad Juarez (Italy). 
21. Tackle incidences of domestic violence and femicide through a multi-pronged approach, including effective legal measures and social awareness programmes (Bangladesh).

22. Provide adequate funding for investigations of violence against women, victim support programmes for affected women, and special training for the police to sensitize them to the problem of violence against women (Austria).

23. Set up structural measures to address systematically violence and violation of fundamental rights, of which women and human rights defenders are victims (Belgium).

24. Continue promoting the bill on enforced disappearances (Colombia).

25. Extend to other federative entities, the categorization of the crime of "forced disappearance" and the full compensation mechanism for victims and members of their families (Uruguay).

26. Take all necessary measures to ensure the effective application of the Federal Act to prevent and punish Torture (Algeria, Portugal).

27 . Take the necessary measures to prevent/prohibit the use of torture/ill-treatment (Japan, Uzbekistan); in particular by security forces in prisons, as noted by a number of special rapporteurs (France).

28. Ensure the timely, effective, and impartial investigations of all allegations concerning torture (Uzbekistan) and combat impunity in this regard (France, Japan).

29. Improve living conditions in prisons (France), and continue to develop measures to improve the situation in prisons and the training of prison officials (Portugal).

30. Curb prevalence of corporal punishment on children, in keeping with Mexico's international advocacy against such offences (Bangladesh), and take measures to ensure that children are fully protected from corporal punishment and other forms of violence or exploitation (Sweden).

31. Address the problems of street children by providing them state protection and vocational training (Pakistan).

32. Take measures to include the crime of trafficking in persons in all parts of the federation and strengthen the resource basis for the protection of victims (Belarus), and strengthen measures to protect and provide assistance to victims, with special emphasis on children victims (Philippines). 
33. Continue efforts to eradicate sexual exploitation of children (Belarus); and to address prostitution, pornography and trafficking of children and adolescents for the purpose of sexual exploitation (Syrian Arab Republic).

34. Promote the implementation of the police and the judiciary reforms (Canada).

35. Continue the Public Security and the Criminal Justice System reforms (Turkey) and ensure that it is being implemented quickly to ensure that human rights violations by the security forces are systematically investigated, perpetrators are brought to justice and victims are compensated (Austria).

36. Review the Code of Military Justice in order to align it more closely with international human rights obligations (Ireland).

37. Recognize the centrality of human rights and the rule of law in its approach to improving public security (New Zealand).

38. Ensure that the rights of detainees are respected (New Zealand).

39. Evaluate the use of "arraigo" (Ireland).

40. Carry out a prompt implementation of the judicial reform to ensure that complaints in cases of torture, arbitrary detention and forced disappearances are exhaustively investigated (Peru), in strict conformity with international human rights standards and adequately involve civil society in this process (Italy).

41. Continue working towards the professionalization and the modernization of the judicial system in all areas, including law enforcement and administration of justice (Palestine).

42. Allocate sufficient financial and human resources for the implementation of the new system of public security and criminal justice, including adequate dissemination of information for users as well as the respective training of judges and lawyers (Chile); devote sufficient resources to the criminal justice and prison systems in an effort to reduce the sentencing backlog (Ireland).

43. Fully investigate all allegations of human rights violations committed by elements of the military and security forces, including the adoption of recommendations made by Mexico National Human Rights Commission (Canada).

44. Fully investigate abuses and human rights violations by law enforcement officials in prisons and ensure that perpetrators are duly punished (Portugal); investigate all allegations of human rights violations 
particularly in relation to persons who were detained during police operations and ensure that perpetrators are properly brought to justice and punished (Uzbekistan).

45. Combat impunity as one of the Government's priorities (Belgium), and make a concerted effort to tackle it nationwide (United Kingdom).

46. Investigate and prevent impunity in cases of human rights violations committed by law enforcement officials, throughout the national territory (Cuba); seriously deal with the allegation of systematic and excessive use of force and torture by law enforcing agencies, to end the culture of impunity (Bangladesh); Investigate the alleged cases of torture and other human rights abuses committed by police, military and security personnel and put an end to the climate of impunity (Azerbaijan); step up efforts to halt torture and ill-treatment, eradicate impunity for such acts and ensure that alleged perpetrators are brought to justice (Denmark).

47. Take firm action to eliminate corruption and impunity in the judicial, security and executive branches (Pakistan); redouble efforts in combating corruption at all levels (Cuba); strengthen measures against corruption and police excesses (Italy); and continue to develop and ensure an effective policy in combating organized crime and corruption (Belarus).

48. Adopt necessary measures to eradicate impunity for human rights violations, particularly against women and indigenous population (Bolivia) and journalists (Sweden).

49. Place high on the agenda the human rights of indigenous peoples when addressing questions of impunity; and improve access to justice for indigenous peoples, including by strengthening public defense for indigenous peoples and providing better translation services (Finland).

50. Fight against organized crime through effective policies (Turkey); and strengthen and share with countries of the region the Government's policies and strategies to combat organized crime at the regional level, and continue regional workshops to share experience for the transfer of knowledge in systems of public security and criminal justice (Honduras).

51. Include human rights aspects in all training programmes and extend them to all police units (Italy); Ensure proper training on human 
rights to members of armed forces, the police, and prison staff and court staff (Switzerland).

52. Publicly recognise the important role of human rights defenders and NGOs in the protection of human rights in Mexico (United Kingdom).

53. Invite NGOs working on press freedom to a constructive dialogue on how Mexico can stop the violence against journalists and ensure press freedom (Norway).

54. Strengthen the rights of journalists and free media; the state as well as the municipal governments should fulfill their responsibility to protect a free media (Germany).

55. Undertake legal reforms to ensure openness and transparency of the media in the country (Russian Federation); review legislation governing radio, television and communication and follow-up on the Supreme Court's ruling for a new legal framework permitting diversity in the media (Netherlands).

56. Put into place more effective measures to tackle violence against journalists and media personnel (United Kingdom); provide greater guarantees to them (Peru); guarantee their safety and security (Bangladesh, Denmark, Peru), when they are discharging their professional duties (Bangladesh), in particular those that investigate and report cases of drug trafficking and corruption (Peru).

57. Create the proper legal framework that gives the Special Prosecutor for Crimes Against Journalists sufficient jurisdiction to investigate and indict perpetrators with greater independence (Netherlands).

58. Investigate cases of attacks / violence and threats against journalists and human rights defenders (Azerbaijan, Germany), in order to bring the perpetrators to justice (Germany); and step up efforts to ensure that investigation of attacks on voices for freedom of expression become a federal issue (Denmark).

59. Ensure that crimes and violations against human rights defenders, journalists and lawyers are effectively investigated and prosecuted; that those responsible are punished; that complaints of threats, harassment and intimidation of human right defenders, journalists and lawyers receive a prompt response and that adequate measures for their safety are taken (Norway).

60. Increase the effectiveness of the "precautionary measures" to protect human rights defenders (Germany), including through adopting 
effective and comprehensive prevention strategies, at central and local levels, to prevent attacks and protect the life and physical integrity of human rights defenders and journalists, and ensure that such programs are backed by a strong political commitment and provided with adequate resources (Norway).

61. Take measures to guarantee freedom of demonstration and ensure protection of demonstrators (France) 62. Continue to strengthen programmes aimed at creating growth and employment (Canada).

63. Continue enhancing the working conditions of temporary agricultural labourers and strengthen the work of labour inspection authorities (Guatemala).

64. Take more concrete measures to eliminate employment and wage gaps, to increase school enrolment rates of indigenous children, and review the justice system (Japan).

65. Combat (Algeria, Honduras) and continue efforts to eradicate (Holy See) extreme poverty (Algeria, Holy See, Honduras).

66. Strengthen efforts / programmes to fight against poverty (Brazil, Canada) and put more financial resources to eradicate it, especially in rural areas (Azerbaijan).

67. Pay special attention to the situation of indigenous people in programmes/strategies to reduce/eradicate poverty (Algeria, Azerbaijan, Philippines) and take measures to reduce that the problem of extreme poverty affecting them (Honduras).

68. Put more efforts and financial resources to eradicate high level mortality and malnutrition rates, especially in rural areas and among indigenous peoples (Azerbaijan).

69. Continue to extend and strengthen the system of primary healthcare and improve the quality of such services (Honduras); and redouble efforts to reduce the number of maternal deaths by training birth attendants and establishing more obstetric clinics (Holy See), with particular attention to indigenous women and peoples (Holy See, Honduras).

70. Continue efforts and take further steps / strengthen the national programme to ensure the right to food (Vietnam), to health (Saudi Arabia, Vietnam), and to education (Saudi Arabia), particularly for the vulnerable groups living in extreme poverty, including indigenous people (Vietnam).

71. Fully implement the Rural Food Support and Supply Programme, the Social Milk Programme, the Living Better Food Supplement Pro- 
gramme and the Comprehensive Food Aid Strategy, with a view to meeting the food requirements of the must vulnerable sections of society (Malaysia).

72. Continue efforts aimed at providing adequate financing for housing to the poorest segments of the population (Malaysia).

73. Ensure the effective access of all children to education, in particular migrant and indigenous children, and take effective measures to combat their exclusion from the education system (Algeria).

74. Seek to improve the enrolment rate of girls in primary and secondary schools (Philippines).

75. Increase efforts to improve the whole system with regard to the indigenous peoples (Azerbaijan); and persevere efforts to build a truly inclusive democracy by fully recognizing the rights of indigenous peoples (Panama); and undertake measures to redress marginalization of indigenous and migrant populations, in line with the prominent role of Mexico in the international scene (Bangladesh).

76. Continue addressing the recommendations made by the Special Rapporteur on the situation of human rights and fundamental freedoms of indigenous people (Guatemala) and invite the relevant special rapporteurs to visit Mexico and make necessary recommendations to uplift the lot of indigenous communities, in line with its commitments and relevant international instruments (Pakistan).

77. Adopt appropriate legislation in full conformity with international standards on the rights of indigenous peoples (Argentina); and take necessary measures to ensure the right of indigenous peoples / other marginalized communities affected by planned economic or development projects to be adequately and fairly consulted (Bolivia, Denmark), in accordance with the commitments undertaken by ratifying ILO Convention No. 169 concerning Indigenous and Tribal Peoples (Bolivia).

78. Strengthen efforts at the federal level to raise awareness of indigenous rights, language and customs, by providing guidance and training to military and local officials, including the police, judiciary, and members of the legal community, particularly in rural areas (New Zealand).

79. Ensure the full realization of the rights of migrants on its territory by enacting legislation and providing training to concerned officials ( $\mathrm{Pa}-$ kistan).

80. Give priority to the recommendations made by the Special Rapporteur on the human rights of migrants (Guatemala). 
81. Take all necessary measures to protect the rights of migrant workers and members of their families, particularly by ensuring their access to justice (Uzbekistan) / their access to an effective remedy before a competent authority for the protection of their rights (Guatemala); and prosecute and punish civil servants responsible for acts of ill-treatment and offences against them (Guatemala).

82. Establish an effective and inclusive process to follow up on the UPR recommendations (Norway); increase dialogue and consultations with civil society organizations in the design of follow-up measures and implementation of the UPR towards strengthening the impact of the human rights policies, as set out in Resolution 5/1 of the Council (Panama).

83. Disseminate the report presented by the Mexican Government, as well as the observations and final recommendations resulting from the UPR, at the national level (Honduras).

94. The following recommendations will be examined by Mexico which will provide responses in due time. The response of Mexico to these recommendations will be included in the outcome report adopted by the Human Rights Council at its eleventh session.

1. Enact a definition of organized crime consistent with the United Nations Convention against Transnational Organized Crime (Portugal).

2. Abolish the practice of "arraigo" (New Zealand, Switzerland) as soon as possible (New Zealand).

3 . Ensure that the primacy of the civil legal system prevail over military judicial process across the entire territory (Bangladesh).

4. Extend the jurisdiction of civil courts in cases involving violations of human rights by the military (Ireland).

5. Follow-up on the recommendations of Committee against Torture and OHCHR to empower civil courts to try offences against human rights, in particular torture and cruel, inhuman or degrading treatment committed by military personnel, even when it is claimed that they were service-related (Portugal).

6. Grant jurisdiction to its civil authorities/courts over the acts/human rights violations committed by members of armed forces when performing law enforcement functions (Republic of Korea, Russian Federation); if the military involvement in combating organized crimes is necessary, the expanded role of the military must be counterbalanced by measures to reinforce the protection of human rights (Republic of Korea). 
7. Review the relevant legal provisions to ensure that all offences committed against human rights by military forces may also be submitted to civil courts (Peru, Uruguay).

8. Re-establish the Special Prosecutor's office for past-political and social movements or create a similar office, which would be a strong signal towards combating impunity for victims and their families (Belgium).

95. All conclusions and/or recommendations contained in the present report reflect the position of the submitting State(s) and /or the State under review thereon. They should not be construed as endorsed by the Working Group as a whole.

\section{VOLUNTARY COMMITMENTS OF THE STATE UNDER REVIEW}

96. In order to strengthen the rule of law with security and justice institutions capable of effectively protecting human rights, and to overcome social inequalities, Mexico commits to adopt the necessary measures to address the recommendations of the Universal Periodic Review in the framework of the National Programme on Human Rights 2008-2012. Mexico will also work in the framework of the Agreement with the Office of the High Commissioner for Human Rights in Mexico in order to foster the implementation of the recommendations.

97. Mexico will follow up on the recommendations with the full participation of civil society and autonomous human rights institutions, through the Commission for Government Policy on Human Rights.

\section{ANNEX}

\section{COMPOSITION OF THE DELEGATION}

The delegation of Mexico was headed by H. E. Sr. Fernando Gómez-Mont, Minister of Interior, and composed of 28 members:

H. E. Sr. Fernando Gómez-Mont, secretario de Gobernación;

Sr. Juan Manuel Gómez Robledo, embajador, subsecretario para Asuntos Multilaterales y Derechos Humanos, Secretaría de Relaciones Exteriores; 
Sr. Luis Alfonso de Alba, embajador, representante permanente ante los Organismos Internacionales con sede en Ginebra;

Sr. Gustavo Merino, subsecretario de Prospectiva, Planeación y Evaluación, Secretaría de Desarrollo Social;

Sra. Ma. Cecilia Landerreche, titular del DIF Nacional, Sistema Nacional para el Desarrollo Integral de la Familia;

Sra. María del Rocío García, presidenta del Inmujeres, Instituto Nacional de las Mujeres;

Sra. Mabel Gómez Oliver, embajadora, representante permanente alterna ante los Organismos Internacionales con sede en Ginebra;

Sra. Sigrid Arzt, secretaria técnica, Consejo de Seguridad Nacional;

Sr. Jaime Antonio López Portillo, general de brigada de Justicia Militar, director general de Derechos Humanos, Secretaría de la Defensa Nacional;

Sr. José Luis Chávez, general de brigada de Justicia Militar, procurador general de Justicia Militar, Secretaría de la Defensa Nacional;

Sr. Alejandro Poiré, coordinador de asesores del secretario de Gobernación, Secretaría de Gobernación;

Sr. Alejandro Negrín, ministro, director general de Derechos Humanos y Democracia, Secretaría de Relaciones Exteriores;

Sr. Pascual Moreno, director general de Atención a Recomendaciones y Amigables Conciliaciones en Derechos Humanos, Procuraduría General de la República;

Sr. Víctor Hugo Pérez, director general de Derechos Humanos, Secretaría de Seguridad Pública;

Sra. Ludka de Gortari, directora general de Evaluación y Control de la Unidad de Planeación y Consulta, Comisión Nacional para el Desarrollo de los Pueblos Indígenas;

Sra. Tania Esparza, directora general en la oficina del c. secretario de la Secretaría de Gobernacion;

Sr. José Antonio Guevara, ministro, Misión Permanente ante los Organismos Internacionales con sede en Ginebra;

Sra. Judith Arrieta, consejera, Misión Permanente ante los Organismos Internacionales con sede en Ginebra;

Sr. Miguel Malfavón, consejero, Misión Permanente ante los Organismos Internacionales con sede en Ginebra;

Sr. Pablo Navarrete, director de Asuntos Internacionales, Instituto Nacional de las Mujeres; 
Sra. Mariana Olivera, segundo secretario, Misión Permanente ante los Organismos Internacionales con sede en Ginebra;

Sra. Ma. Victoria Romero, segunda secretaria, Misión Permanente ante los Organismos Internacionales con sede en Ginebra;

Sr. Salvador Tinajero, tercer secretario, Misión Permanente ante los Organismos Internacionales con sede en Ginebra;

Sr. Gustavo Torres, asesor, Misión Permanente ante los Organismos Internacionales con sede en Ginebra;

Sra. Gracia Pérez, asesora, Misión Permanente ante los Organismos Internacionales con sede en Ginebra;

Sra. Omeheira López, presidenta de la Comisión de Derechos Humanos, Cámara de Diputados;

Sra. Alliet Bautista, secretaria técnica, Comisión de Derechos Humanos, Cámara de Diputados;

Sra. Cristina Hárdaga, asesora en derechos humanos, Cámara de Diputados. 